\title{
PENGARUH METODE PEMBELAJARAN PROBLEM BASED \\ LEARNING TERHADAP HASIL BELAJAR SISWA PADA MATA PELAJARAN ADMINISTRASI SISTEM JARINGAN
}

\author{
Iva Rahmatillah ${ }^{1}$, Arico Ayani Suparto ${ }^{2}$, Irma Noervadila ${ }^{3}$ \\ Email: Ivarahmatillahpti@gmail.com, caca13rico@gmail.com, \\ noervadilairma@gmail.com.
}

Received: June15, $2021 \quad$ Revised: June 20, $2021 \quad$ Accepted: June 27, 2021

\begin{abstract}
ABSTRAK
Penelitian ini bertujuan untuk mengetahui pengaruh metode pembelajaran Problem Based Learning terhadap hasil belajar siswa kelas XI TKJ di SMK Nurul Huda Kapongan. Penelitian ini merupakan penelitian kuantitatif dengan model Pre experimental design dengan suatu bentuk penelitian secara One group pretest posttest design. Responden dalam penelitian ini adalah seluruh peserta didik kela XI TKJ SMK Nurul Huda Kapongan yang berjumlah 31 peserta didik. Teknik pengumpulan data yang dilaksanakan meliputi nilai hasil mata pelajaran Administrasi Sistem Jaringan belajar yang menggunakan pretest dengan posttest. Data hasil belajar di terjemahkan dalam skor Gain untuk mengetahui perbedaan hasil belajar sebelum atau sesudah menggunakan metode pembelajaran Problem Based Learning. sedangkan uji hipotesis menggunakan uji paired sampel T-test dengan uji regresi linier sederhana. Hasil dari uji paired sampel T-test diperoleh sebesar -3,503 dengan nilai signifikansi 0,001 < taraf signiikansi 0.05. Hasil uji regresi linier sederhana sebesar 14,2\% hal ini menunjukkan bahwa problem based learning mempunyai pengaruh yang positif dan signifikan terhadap hasil belajar siswa.
\end{abstract}

Kata kunci : Problem Based Learning, Hasil Belajar.

\section{ABSTRACT}

This study aims to determine the effect of the Problem Based Learning method on the learning outcomes of class XI TKJ students at SMK Nurul Huda Kapongan. This research is a quantitative research with pre experimental design with a form of research in one group pretest posttest design. Respondents in this study were all students of class XI TKJ SMK Nurul Huda Kapongan totaling 31 students. The data collection techniques carried out included the results of the learning network system administration subject using a pretest with a posttest. Learning outcomes data are translated into Gain scores to determine differences in learning outcomes before or after using the Problem Based Learning learning method. while the hypothesis test uses a paired sample T-test with a simple linear regression test. The results of the paired sample T-test were obtained at -3.503 446 JURNAL IKA PGSD UNARS VOL.10 No.2 DESEMBER 2021 
with a significance value of $0.001<0.05$ significance level. The results of a simple linear regression test of $14.2 \%$ indicate that problem based learning has a positive and significant influence on student learning outcomes.

\section{Keywords: Problem Based Learning, Learning Outcomes.}

\section{PENDAHULUAN}

Pendidikan adalah suatu usaha dan sudah terencana dalam mewujudkan suatu hasil belajar dan peserta didik dengan aktif dalam mengembangkan potensi dirinya untuk memiliki suatu kekuatan dari keagamaan kepribadian pengendalian diri ahlaq mulia dan kecerdasan yang dibutuhkan oleh dirinya bangsa dan Negara dan dalam pendidikan di Indonesia telah memiliki tujuan mengembangkan suatu potensi siswa agar bisa menjadi manusia yang bertaqwa dan beriman kepada Allah SWT dan menjadi warga Negara yang demokrasi serta bertanggung jawab. Dan tujuan dalam pendidikan adalah dasar kecerdasan, kepribadian, pengetahuan, ahlaq mulia, dan hidup mandiri dan pendidikan.

Pengaruh model Problem Based Lerning di maksud untuk mengetahui kemampuan mengembangkan keterampilan berfikir, keterampilan memecahkan masalah, melatih kemandirian, motivasi belajar, dan juga hasil belajar peserta didik dalam pelaksanaan pembelajaran ini siswa bagaimana menggunakan/ konsep dan proses berinteraksi untuk bisa menilai apa yang mereka ketahui, dan juga peserta didik dapat menumbuhkan keterampilan berfikir kreatif untuk menyelesaikan masalah,bertindak sebagai pemecahan masalah di dalam pembelajaran dan juga pembelajaran di bagun proses berfikir, kerja kelompok, berkomunikasi dan saling memberi motivasi.

Pada jurnal penelitian (Wulandari \& Surjono, 2013) “ pengaruh problem based learning terhadap hasil belajar di tinjau dari motivasi belajar PLC di SMK" Pembelajaran yaitu merupakan suatu proses interaksi di antara guru dengan siswa dan beserta unsur didalamnya dan guru adalah merupakan faktor yang paling dominan dan juga guru yang bisa menentukan suatu kualitas pembelajaran siswa dan suatu kualitas pembelajaran yang baik, yang akan menghasilkan suatu hasil belajar yang lebih baik lagi,dalam suatu pembelajaran guru dituntut untuk mampu memilah dan memilih metode pembelajaran yang bagus dan baik untuk peserta didiknya, dan juga mampu menggunakan dengan baik alat evaluasi, mampu 
mengelola pembelajaran dikelas maupun di ruang praktik dengan efektif dan efisien, menguasai materi, dan memahami masing-masing karakter peserta didik, dan merupakan suatu tuntutan bagi seorang guru yang harus bisa memilih suatu metode pembelajaran yang tepat dan baik ketika mengajar peserta didik di dalam kelas.

Pada jurnal penelitian (Amin, 2017) "pengaruh model pembelajaran problem based learning terhadap berpikir kritis dan hasil belajar Geografi " secara empirik dalam pengruh model pembelajaran problem based learning bagi hasil belajar peserta didik yang didukung oleh hasil penelitian bahwa " sudah terdapat perbedaan yang signifikan antara hasil belajar pada mata pelajaran fisika dan antara peserta didik pada kelas X SMKN 1 blitar yang dalam pembelajaran menggunakan model pembelajaran problem based learning dan pembelajaran yang konvensional, dari suatu hasil belajar dari kelompok metode pembelajaran problem based learning hasilnya lebih baik dari pembelajaran kelompok yang konvensional, dan juga hasil penelitian yang telah menunjukkan bahwa, suatu hasil belajar dari mata pelajaran IPA kelas VIII SMPN 2 blitar yang sudah menggunakan suatau pembelajaran problem based learning dan perbandingannya lebih tinggi dari pada siswa yang mengikuti pembelajaran secara konvensional.

\section{Tujuan Penelitian}

Ialah untuk mengetahui ada pengaruh atau tidak tentang metode pembelajaran problem based learning terhadap hasil belajar siswa pada mata pelajaran administrasi sistem jaringan kelas XI TKJ SMK Nurul Huda Kapongan.

\section{Rumusan Masalah}

Permasalahan proses kegiatan belajar mengajar di SMK Nurul Huda Kapongan adalah pada saat proses pembelajaran teori, peserta didik kurang semangat dan kurang aktif dalam mengikuti pembelajaran. Hal tersebut disebabkan karena materi yang disampaikan oleh guru kurang dapat diterima secara maksimal oleh siswa, sehingga akan berdampak pada hasil belajar siswa SMK Nurul Huda Kapongan.

\section{METODE PENELITIAN}

Metode penelitian kuantitatif ini adalah sebuah metode penelitian yang berdasarkan sebuah bukti empiris untuk melakukan sebuah investigasi sebuah 
fenomena social yang melalui prinsip-prinsip statistik, dari tujuan metode penelitian kuantitatif ini adalah untuk mendapatkan sebuah pola atau suatu model matematis yang membuktikan sebuah teoris dan sebuah hipotesis yang dibentuk oleh peneliti.

Penelitian ini adalah suatu penelitian Pre experimental design dengan suatu bentuk penelitian secara One group pretest posttest design. Menurut Sugiyono (2015:74) penelitian Pre experimental design (non design) adalah suatu jenis penelitian yang belum merupakan experiment sungguh-sungguh, dikarenakan masih terdapat satu variabel dependen yaitu bisa di sebut variabel (X), jadi hasil dari experiment yang merupakan variabel dependen variabel (X) bukan hanya di pengaruhi oleh suatu variabel independen yaitu variabel (Y). jadi alasan kenapa menggunakan desaign penelitian seperti ini ialah karena hanya ada satu kelompok atau hanya ada satu kelas yang digunakan dalam penelitian ini dan sehingga tidak ada kelompok yang digunakan sebagai pembanding. Dan pada design ini perlakuan di berikan sebelum dan seudah. Dan demikian dari hasil penelitian ini dapat di ketahui lebih akurat, karena bisa di bandingkan dengan keadaan sebelum diberi perlakuan. Menurut (Sugiyono, 2014: 74)

\section{Problem Based Learning.}

Variabel dalam penelitian ini terdiri dari variabel independen dan variabel dependen. Variabel independen atau variabel bebasnya adalah Problem Based Learning. Variabel dependen atau variabel terikatnya adalah hasil belajar siswa. Penelitian ini dilakukan untuk menyelidiki ada tidaknya pengaruh tersebut dengan cara diberi tes awal (pretest) dengan tes yang sama pembelajaran pada kelas memperoleh perlakuan dengan menggunakan metode pembelajaran Problem Based Learning Pada akhir pertemuan siswa diberi (posttest), yaitu dengan memberikan tes kemampuan penyelesaian soal yang dilakukan pada kelas sampel dengan soal tes yang sama untuk mengetahui hasil belajar siswa.

Pemilihan lokasi penelitian dipilih berdasarkan pertimbangan sesuai tujuan peneliti yaitu secara (Purposive). Purposive Sampling Area merupakan salah satu teknik pengambilan sampel yang sering digunakan dalam penelitian. Penelitian ini menggunakan sebuah metode pengambilan sampel dengan teknik Purposive Sampling. Dapat diambil kesimpulan, peneliti menentukan sendiri 
lokasi yang akan diambil dengan pertimbangan tertentu. Jadi, peneliti memilih sendiri lokasi yang akan dijadikan tempat penelitian, alasannya karena belum pernah diteliti mengenai pengaruh metode pembelajaran problem based learning terhadap hasil belajar siswa pada mata pelajaran administrasi sistem jaringan kelas XI TKJ SMK Nurul Huda kapongan.

\section{Tabel 3.1 Jumlah Siswa Kelas XI TKJ}

\begin{tabular}{cc} 
KELAS & JUMLAH SISWA \\
\hline XI & 31 \\
\hline JUMLAH & 31
\end{tabular}

Untuk menentukan responden penelitian peneliti menggunakan secara sampel. Sampel merupakan bagian dari sebuah jumlah dan karakteristik yang sudah dimiliki oleh populasi tersebut. Menurut Arikunto (2013), dan sampel adalah sebuah bagian atau sebuah wakil dari populasi yang akan diteliti.

Teknik yang digunakan dalam menentukan sampel dari penelitian ini adalah purposive sampling. Purposive sampling adalah teknik pengambilan sampel yang telah digunakan oleh peneliti bukan secara acak dan dengan pertimbangan tertentu. Pertimbangan ini, misalnya karena waktu, tenaga dan keterbatasan dana, maka penulis juga dapat menggunakan sampel yang sudah diambil dari populasi tersebut.

Data hasil belajar pada mata pelajaran Administrasi Sistem Jaringan di terjemahkan dalam skor Gain. Untuk mengetahui perbedaan hasil belajar sebelum atau sesudah menggunakan metode pembelajaran Problem Based Learning untuk mendapatkan skor Gain dengan cara mengurangkan skor pretest dengan postest secara matematis.

$$
\begin{aligned}
& \text { Indeks gain }=\frac{\text { Skor posttest }- \text { skor pretest }}{\text { Skor maksimum }- \text { skor pretest }} \\
& \qquad \begin{aligned}
\text { Indeks gain } & =\frac{2460-2280}{3100-2280} \\
& =\frac{180}{820}
\end{aligned}
\end{aligned}
$$




$$
=0,21
$$

Berdasarkan kreteria nilai N-Gain dalam tingkat aktivitas dan yang tertera dalam Bab III, Nilai N-Gain 0,21 - 0,40 dapat diartikan hasil belajar siswa dikategorikan rendah, sehingga hipotesis yang berbunyi “ Pengaruh Motode Pembelajaran Problem Based Learning Terhadap Hasil Belajar Siswa Pada Mata Pelajaran Administrasi Sistem Jaringan Kelas XI TKJ SMK Nurul Huda Kapongan" dikategorikan rendah.

\section{Tabel 3.3 Kriteria Gain Ternormalisasi (N-GAIN)}

\begin{tabular}{cc} 
Rentang & Kriteria \\
\hline $0,81-1,00$ & Sangat Tinggi \\
\hline $0,61-0,80$ & Tinggi \\
\hline $0,41-0,60$ & Sedang \\
\hline $0,21-0,40$ & Rendah \\
\hline $\mathrm{g} \leq 0,20$ & Sangat Rendah
\end{tabular}

Pengujian hipotesis pada penelitian ini dengan cara membandingkan nilai Sig. (2-tailed) pada Paired Sample t-Test dengan nilai $\alpha(0,05)$ dengan kriteria uji sebagai berikut:

1. Jika nilai Sig. (2-tailed) < 0,05 maka H0 ditolak dan Ha diterima.

2. Jika nilai Sig. (2-tailed) > 0,05 maka H0 ditolak dan Ha diterima.

Pada penelitian ini uji paired sampel T-test juga dilakukan dengan menggunakan bantuan program SPSS 24 dan Dari hasil uji paired sampel T-test pada program SPSS 24, di ketahui bahwa nilai dari sig, (2- tailed) sebesar 0,001, yaitu sesuai dengan dasar ketentuan pengambilan keputusan dalam uji paired sampel T-test bahwa pada nilai sig, (2- tailed) $<0.05$ atau 0,001<0,05, maka Ho di tolak dan Ha di terima, dan dapat di simpulkan bahwa terdapat perbedaan yang signifikan antara hasil test pre test dengan post test yang artinya ada pengaruh terhadap penggunaan metode pembelajaran prolem based learning pada hasil belajar siswa pada mata pelajaran administrasi sistem jaringan Kelas XI TKJ di 
SMK Nurul Huda Kapongan.

Tabel 3.4 Kriteria Interprestasi Koefisien

\begin{tabular}{cc} 
Interval Koefisien & Tingkat Hubungan \\
\hline $0,00-0,199$ & Sangat Rendah \\
\hline $0,20-0,399$ & Rendah \\
\hline $0,40-0,599$ & Sedang \\
\hline $0,60-0,799$ & Kuat \\
\hline $0,80-1,000$ & Sangat Kuat
\end{tabular}

Sumber: Sugiyono, (2014)

Pada penelitian ini uji regresi linier sederhana dilakukan dengan menggunakan bantuan dari program SPSS 24 (Statistical Package For Social Sciense), dan di temukan hasil dari perhitungan uji regresi linier sederhana maka di dapatkan hasil output sebagai berikut:

Didalam kriteria penentuan uji regresi linier sederhana ditentukan, bahwa apabila data yang di analisis ialah menggunakan satu variabel bebas maka hasil hitungan yang digunakan ialah nilai $\mathrm{R}$ Square, karena penelitian ini hanya menggunakan satu variabel bebas maka hasil hitungan yang digunakan ialah $\mathrm{R}$ Square.

Dari hitungan yang telah diketahui bahwa besarnya nilai R Square ialah 0,142 atau sama dengan $14,2 \%$ hal ini telah menunjukkan bahwa besarnya nilai persentase pengaruh pada variabel bebas terhadap variabel terikat adalah sebesar $14,2 \%$.

\section{HASIL DAN PEMBAHASAN}

Pada hasil uji paired sampel T-test telah menunjukkan bahwa terdapat perbedaan yang signifikan antara hasil pretest dengan hasil posttest yang artinya ada pengaruh penggunaan metode pembelajaran Problem Based Learning pada mata pelajaran Administrasi Sistem Jaringan Kelas XI TJK di SMK Nurul Huda Kapongan, karena pada tabel 4.3 hasil uji Paired Sampel T-test SPSS 24, di $\mathbf{4 5 2}$ | JURNAL IKA PGSD UNARS VOL.10 No.2 DESEMBER 2021 
ketahui bahwa nilai sig, (2-tailed) sebesar 0,001 yang sesuai dengan dasar pengambilan keputusan pada uji Paired Sampel T-test bahwa nilai sig, (2- tailed) $<0,05$ atau $0,001<0,05$, maka HO di tolak dan Ha di terima, sehingga dapat disimpulkan kembali bahwa terdapat perbedaan yang signifikan antara hasil pretest dengan hasil posttest.

Dan kemudian pada uji regresi linier sederhana menunjukkan dukungan penuh untuk hipotesis, karena pada tabel 4.4 hasil uji regresi linier sederhana SPSS 24 telah di peroleh koefisien determinasi (R Square) sebesar 0,142 atau sama dengan $14.2 \%$, dan hal ini berarti pada variabel bebas (metode pembelajaran Problem Based Learning) di jelaskan bahwa sebesar 14,2 \% oleh variabel terikat yaitu (hasil Belajar), dan hal ini menunjukkan bahwa variabel bebas berpengaruh sebesar $14,2 \%$ terhadap variabel terikat sedangkan sisanya $85,8 \%$ di pengaruhi oleh variabel lain diluar penelitian yang tidak di masukkan pada model regresi. Dan berdasarkan pada tabel kriteria interprestasi koefisien yang sebagaimana tertera dalam bab III, bahwa nilai (R Square) 0,00-0,199 di kategorikan sangat rendah, sehingga dapat disimpulkan bahwa metode pembelajaran Problem Based Learning telah memberikan pengaruh yang sangat rendah terhadap hasil belajar siswa, Alasan kenapa pengaruhnya sangat rendah adalah, karena peneliti melakukan penelitian di masa pandemi covid-19 sehingga pembelajaran di sekolah tidak berjalan dengan efektif dan efisien.

\section{KESIMPULAN}

Berdasarkan analisis data dan pengujian hipotesis yang meliputi analisis nilai N-Gain, uji Paired Sampel T-test, dan analisis Regresi Linier Sederhana dan pengujian Paired Sampel T-test diketahui bahwa nilai yang di peroleh adalah $<0,05$ maka keputusan yang di ambil ialah Ho ditolak dan Ha diterima, dan dapat di simpulkan bahwa adanya perbedaan yang signifikan antara hasil pretest dengan hasil posttest yang artinya ada pengaruh metode pembelajaran problem based learning terhadap hasil belajar siswa pada mata pelajaran Administrasi Sistem Jaringan Kelas XI TKJ SMK Nurul Huda Kapongan. Dan dimana yang telah dilaksanakan uji regresi linier sederhana bahwa besarnya nilai persentase pengaruh pada variabel bebas terhadap variabel terikat adalah sebesar 14,2\% 


\section{DAFTAR PUSTAKA}

Amin, S. (2017). Pengaruh Model Pembelajaran Problem Based Learning Terhadap Kemampuan Berpikir Kritis Dan Hasil Belajar Geografi. Jurnal Pendidikan Geografi, 4(3), 25-36.

Arikunto. (2013). Proportional Stratified Random Sample. Dictionary of Statistics \& Methodology, 02(01). https://doi.org/10.4135/9781412983907.n1534

Disampaikan Pada Kegiatan Pelatihan Metodologi Penelitian Pendidikan, Mp. (2013). Penelitian Ex Post Facto.

Farisi, A., Hamid, A., \& Melvina. (2017). Pengaruh Model Pembelajaran Problem Based Learning terhadap Kemampuan Berpikir Kritis dalam Meningkatkan Hasil Belajar Ssiswa pada Konsep Suhu dan Kalor. Jurnal Ilmiah Mahasiswa, 2(3), 283-287.

Hariyadi, A. B., \& Hariyati, N. (2020). Pentingnya fasilitas belajar berbasis teknologi informasi terhadap hasil belajar siswa. Jurnal Inspirasi Manajemen Pendidikan, 08(04).

Iqbal, M. (2021). Rancangan Aplikasi Pendataan Penerimaan Siswa Baru Smp Nurul Ihsan Jakarta Berbasis Android. 1417-1423.

Jacub, T. A., Marto, H., \& Darwis, A. (2019). Model Pembelajaran Problem Based Learning Dalam Peningkatan Hasil Belajar Ips (Studi Penelitian Tindakan Kelas Di Smp Negeri 2 Tolitoli). Tolis Ilmiah; Jurnal Penelitian, 1(2).

Kadir, A. (2015). MENYUSUN DAN MENGANALISIS TES HASIL BELAJAR Abdul Kadir. Al-Ta'dib, 8(2).

mely cholifatul jannah, antonius tri widodo, K. (2018). Pengaruh Model Problem Based Learning Terhadap Hasil Belajar Dan Keterampilan Proses Sains. Jurnal Inovasi Pendidikan Kimia, 12(1).

Metariawan, G. dkk. (2017). Pengembangan Multimedia Interaktif Berorientasi Model Inkuiri Pada Mata Pelajaran Pemrograman Dasar Untuk Siswa Kelas X Jurusan Multimedia Di Smk Negeri 1 Sukasada. 5(1).

Rini, C. S., Sitompul, N. C., \& Wiyarno, Y. (2021). pengembangan E-PUB untuk Administrasi Sistem Jaringan. Jurnal Kajian Teknologi Pendidikan, 6(1).

Sugiyono. (2014). Pengaruh Harga Jual Kaca Patri Jenis Silver Terhadap Nilai Penjualan Pada Cv. Karunia Kaca Palembang Tahun 2004-2015. Jurnal Ecoment Global, 2(2), 49. https://doi.org/10.35908/jeg.v2i2.251 
Sundayana. (2014). Metode Penelitian Metode Penelitian. 2, 22-34.

Udin Supriatna. (2017). Metode Penelitian Metode Penelitian. 22-34.

Wulandari, B., \& Surjono, H. D. (2013). Pengaruh problem-based learning terhadap hasil belajar ditinjau dari motivasi belajar PLC di SMK. Jurnal Pendidikan Vokasi, 3(2). https://doi.org/10.21831/jpv.v3i2.1600 